\title{
"Alternative" Assessment: Performance Tests in Microteaching Class
}

\author{
Sri Yuliani \\ Universitas Islam Riau \\ Riau Pekanbaru - Indonesia \\ sriyuliani@edu.uir.ac.id
}

\begin{abstract}
The aim of the research was to find out whether alternative assessment for performance tests in microteaching class at English study program FKIP UIR was suitable. This research was based on the preliminary studies in English study program in teaching and learning process of Microteaching class. The phenomenon occured while teaching and learning process in the classroom, some assessments tools were applied, however the researcher would like to find the most appropriate assessment tool. This research employed a combination of quantitative and qualitative research methods. In quantitative, the research featured a documentation design based on the students' performance score in demonstrating their microteaching skills. In its qualitative dimension, the study employed analysis observation where data were collected and analysed based on the observation done during microteaching class. Semester 6 students were the population of the research and 20 sample students were chosen. Performance test was applied to evaluate the progress of microteaching performance and it was found that alternative assessment was considered effective that it could be used to improve the quality of English study program students in microteaching class.
\end{abstract}

Keywords: Alternative assessment, Performance test, Microteaching

\section{INTRODUCTION}

Microteaching is an early stage in the establishment of training of basic teaching competence through teaching. Basically microteaching is a learning method based on the Performance of the technique is done by training components of competency elementary teaching (teaching skills) in the learning process so that prospective teachers are really able to control each component one by one or several an integrated component in a simplified learning situations or diminished seen from the aspect of learning components, materials students, as well as time.

A number of educational courses and field studies, either in the form of theory and practice has to be learned and drilled before the implementation of the Field Experience Program (PPL). One of course is a very important practice teaching or microteaching. Completion of this course is a requirement for student teachers to follow the Field Experience Program (PPL). Not just a requirement, but through this microteaching actual student teachers prepare and get real experience in practice teaching. If the implementation of learning microteaching runs well, it will give a lot benefits for prospective teachers.
Lecturing is a process of forming the students to have a certain competence. KKNI has been used as a descriptive reference for university level of education in Indonesia to determine the graduate competency. They are expected to be able to achieve the competencies that have been prepared by the drafting team of the curriculum. These competencies can be useful for the graduates to interact with society. The scholar must have a minimum depth of material, based on Ministry of education rules No. 49 Year 2014 section 9 "the scholar is expected to cover at least the theoretical concepts of knowledge and particular skills in the field of knowledge in depth", so that in learning process, the lecturer must fully understand with which competency that must be achieved by a subject. There is possibly a paradigm which cannot be avoided in measuring competency temporarily done during or after class.

An effort to improve the quality of learning, an educator and prospective educators should be able to master the material and the governance of a class in the teaching learning process. This mastery is obtained through the exercises or the practice of good fellow prospective lecturers directly in the field or practice (PPL) for prospective lecturers. This kind of activity is known as micro teaching (learning / teaching micro) which experts in providing mutual understanding of different but essentially the same. Laughlin and Moulton define micro teaching (teaching micro) is an exercise method designed appearance clearly to isolate the component parts of the process of teaching, so that lecturers (future lecturers) can dominate each component individually in a simplified teaching situations.

Unit Field Experience Program (UPPL) FKIP-UIR (2016) microteaching is generally aimed at preparing student teachers to face the job taught entirely in front of the class have the knowledge, skills, and attitudes as professional teachers. Students' success in running Field Experience Program (PPL) is influenced by many factors. These factors can be derived from self (internal) or from outside student self (external), for Field Experience Program (PPL) a blend of theoretical and practical abilities.

Microteaching is a classroom application which one of the teachers' education technique in evaluating the students' competency combine with training and diagnostic tool in teachers' intern program at FKIP UIR especially in English study program. The technique allows candidate 
teachers define teaching skills and performance. The pedagogic skill for teaching can be acquired only through more structured and cheaper faculty training techniques.

The art of teaching does not merely involve a simple transfer of knowledge from one to other. Instead, it is a complex process that facilitates and influences the process of learning. Quality of a teacher is estimated on how much the students understand from his/her teaching. The classrooms cannot be used as a learning platform for acquiring primary teaching skills. Moreover, many efforts and trainings have been done to undertake of microteaching framework, there were some lacks and needs to improve the quality of English study program students at FKIP UIR to implement this subject in the classroom.

The other needs of the outcomes of education in FKIP UIR is to satisfy the employment needs of employers (in this case users in various school) and graduates. Graduates seek to obtain lucrative employment opportunities and employers pursue suitable new recruits from the pool of graduates to fill job offerings. Community colleges foster the employment opportunities of their students by integrating theoretical and practical training. The practical training component involves collaborating with employers to provide work experience for students. The work experience program aims at providing hands-on training in technical skills and helps students integrate other personal and professional skills relevant for employment. Even with the work experience component, the training opportunities provided by the community college prove inadequate for some employers. Further evidence of these conclusive statements is discussed in the rationale and the literature review. The community college of interest to the project study needs to be deliberated about the training and assessment of students' development of Microteaching.

The commitment to improve the graduates, it leads the researcher to elaborate and find the alternative assessment in microteaching class by evaluating the students candidate teacher to do performance test as one of the tools in measuring the teaching competence.

\section{METHOD}

The type of this research was a mixed method, a combination of quantitative and qualitative research methods. In quantitative, the research featured a documentation design based on the students' performance score in demonstrating their microteaching skills. In its qualitative dimension, the study employed analysis observation where data were collected and analysed based on existing framework of microteaching scoring rubrics.

The population of the research was 6th semester students that administered English language program Microteaching (3 credits). There were 7 microteaching classes; 6A class to $6 \mathrm{G}$. The researcher chose 20 students to be the sample of the research by using random sampling technique.
There were two competences as the main objectives of the research. First was the students ability to describe or to explain in practicing microteaching subject. The second was the students' ability to write Lesson Plan which was collected during the presentation done. There were two instruments used by researchers namely microteaching tests or teaching practice, and observation sheet.

In the first step, the researcher done was preparing the assessment rubric to determine all activities or products that were assessed. Activities or products were based on competence or microteaching learning objectives to be achieved. Activities that seen in the rubric were microteaching performance/how a practicant explained, composed a lesson plan.

The second step was to determine assessment criteria. These criteria were taken from competence achieved by the researchers, desired and also expectations achieved by students. The criteria to be used in the assessment were taken / adapted from several sources including guide books Implementation and Assessment Practice PPL and "Becoming a Professional Master" book. Another way to easy in determining the rubric assessment criteria can be found on the website such as rubistar.com rubric criteria. This site provide assessment rubric. However, the criteria in this site needed to check its validity and reliability, hence researchers prefer these 2 above book as a reference source. Microteaching activities in the course of this presentation focused on 8 criteria consisting of: 1) Start / Open; 2) The control material; 3) Effectiveness; 4) Vocal; 5) Variation; 6) The timing; 7) Performance; 8) closing/ terminate; 9) Preparation of the RPP; and 10) The management of activities in RPP (Lesson Plan).

The third step was to determine levels of each criteria. In the assessment rubric used four levels (rating scale) and each level has a value equal to the level. Level 4 worth 4 has the meaning of "very good". Level 3 was worth 3 has the meaning of "Good". Level 2 has a value of 2 has the meaning of "Enough". Level 1 worth 1 has the meaning of "Bad". Each level has its criteria.

Performance test was done after completing all those instruments and the student got the execution was performed for about 20-15 minute in the classroom. In evaluating the students' performance, the lecturer acted as the resource person, supervisor, advisor, and rater while the video recording was recorded the students' performance. The purpose of video recording was to replay the entire lesson during performance test. The lecturer needed to point out some objective to be evaluated and to focus for some feedback to clarify of some gap points..

\section{FINDING AND DISCUSSION}

The beginning of the microteaching performance, each of 20 students got an overview of items that they should have to be prepared for the evaluation. The purpose of this activity was to review the beginning performance, video tape recording, and evaluation system. The evaluation scoring of the performance were made by both microteaching team and microteaching lecture called Implementation and Assessment Practice PPL of FKIP UIR. The Implementation and 
Assessment Practice PPL used here because the researcher wanted to obtain an overall teaching performance evaluation rather than an evaluation of one particular skill.

Next, to determine assessment criteria. These criteria were taken from performance competence achieved by the researcher and team, desired and also expectations achieved by students. The criteria to be used in the assessment were taken / adapted from several sources including guidebooks Implementation and Assessment Practice PPL and "Becoming a Professional Master" book. Microteaching activities in the course of this presentation focused on 3 criteria consisting of: Presentation Skill - Closure as the final assessment in form of three indicators of an assessment rubrics Organization/Structure (Introduction: Welcome the Audience, Introduce the Topic, Explain the Structure, Body: Clear, Logic, Relevant Full of Fact, and Example), Delivery (Language: Correct Usage, Appropriate Grammar and Vocabulary, Pronunciation Intelligibility, Performance: Body Language, Eye contact, Voice, Physical Organization, Mastery of the Subject: Dept / Detail, Spoken not Reading, Aids: Slides Formal, non Formal), Reflection (Conclusion: Sum up, Thanks to the Audience, Overall Impression: Very Interesting, Pleasant and Very Good or Very Boring, Unpleasent to Listen and Poor Communication). The table data below was the scoring of performance assessment. Each students was evaluated in form of each indicators in scoring rubrics.

Having finished all performance evaluation, the analysis was made to estimate the whole students' achievement in performing their skill in teaching. To avoid any unbiased data, the researcher and PPL team discussed together to accomplish the score. Since this analysis requires several activities of the same performance, only the individual student score was used. Thus improvement in each students' performances were estimated by combining score from teams.

TABLE I. THE SCORE OF INDICATORS IN MiCROTEACHING Class

\begin{tabular}{|c|c|c|c|c|}
\hline No & Name of Student & $\begin{array}{c}\text { Organization/ } \\
\text { Structure }\end{array}$ & Delivery & Reflection \\
\hline 1. & Student 1 & 3 & 4 & 4 \\
\hline 2. & Student 2 & 3 & 3 & 3 \\
\hline 3. & Student 3 & 3 & 3 & 3 \\
\hline 4. & Student 4 & 4 & 4 & 4 \\
\hline 5. & Student 5 & 4 & 3 & 4 \\
\hline 6. & Student 6 & 4 & 3 & 3 \\
\hline 7. & Student 7 & 3 & 2 & 2 \\
\hline 8. & Student 8 & 4 & 4 & 4 \\
\hline 9. & Student 9 & 4 & 4 & 4 \\
\hline 10 & Student 10 & 3 & 2 & 2 \\
\hline 11 & Student 11 & 3 & 2 & 2 \\
\hline 12 & Student 12 & 3 & 3 & 3 \\
\hline 13 & Student 13 & 3 & 3 & 3 \\
\hline 14 & Student 14 & 3 & 3 & 3 \\
\hline 15 & Student 15 & 4 & 4 & 4 \\
\hline 16 & Student 16 & 4 & 4 & 4 \\
\hline 17 & Student 17 & 3 & 2 & 3 \\
\hline \multicolumn{2}{|r|}{ TOTAL } & 58 & 54 & 55 \\
\hline \multicolumn{2}{|r|}{ MEAN } & 3,41 & 3,18 & 3,24 \\
\hline
\end{tabular}

Table 1 shown the analysis of the scoring for the skill represent the significat level which means that the data showed that from these three indicators each score was around three. The average gain of the individual students was in good level. The organization/structure showed the best level as amount as 3,41 , the analysis showed that each students was already obtained the comprehending subject matter in Introduction: Welcome the Audience, Introduce the Topic, Explain the Structure, Body: Clear, Logic, Relevant Full of Fact, and Example. While in delivery showed the gain result was the lowest score of 3,18 , although it means good but it seems the students was still had difficulty in delivery subject matter namely; Language: Correct Usage, Appropriate Grammar and Vocabulary, Pronunciation Intelligibility, Performance: Body Language, Eye contact, Voice, Physical Organization, Mastery of the Subject: Dept / Detail, Spoken not Reading, Aids: Slides Formal, non Formal , and the last was reflection, the gain result showed at score of 3,24, it was in the middle score result and also in the same category was good. So, it noted that in sake of three indicators showed the effectiveness of the alternative assessment rubrics to be applied in microteaching subject.

\section{Organization/Structure}

Organization/Structure (Introduction: Welcome the Audience, Introduce the Topic, Explain the Structure, Body: Clear, Logic, Relevant Full of Fact, and Example). The result of the students' performance assessment showed that in terms of Introduction: Welcome the Audience, Introduce the Topic, Explain the Structure, Body: Clear, Logic, Relevant Full of Fact, and Example area there are significant significant effect of the scores (mean values respectively $\mathbf{3 , 4 1}$ ), the Level 3 was worth 3 has the meaning of "Good". This result shows that the performance assessment in form of Introduction with some sections inside the item showed good level. It shows that teacher candidates improved their teaching performance during learner- centered micro teaching.

\section{Delivery}

Delivery (Language: Correct Usage, Appropriate Grammar and Vocabulary, Pronunciation Intelligibility, Performance: Body Language, Eye contact, Voice, Physical Organization, Mastery of the Subject: Dept / Detail, Spoken not Reading, Aids: Slides Formal, non Formal). The results showed that the mean values respectively $\mathbf{3 , 1 8}$, the level 3 was worth 3 has the meaning of "Good". This result showed that performance assessment of teacher candidates improved their teaching skill. Delivery constituted one of the main stages of performance assessments rubrics score with score of 3,18 .

\section{Reflection}

Reflection (Conclusion: Sum up, Thanks to the Audience, Overall Impression: Very Interesting, Pleasant and Very Good or Very Boring, Unpleasent to Listen and Poor Communication) shows a significant effectivenes with the score value was 3,24 with Good level. This shows that the performance assessment scoring rubric could give the result of scoring value of students in good level and it means that the reflection was good. 
The observation was done during the process of the students were performing their teaching skills, the researcher collaborated with team to observe the activities of microteaching. The usage of alternative assessment was really helpful however to accommodate the efficiency of the evaluation. Each student was observed individually based on the microteaching observation. Student 1 was observed by the researcher and teams that she was in trouble in welcoming the audience, it seemed that she was nervous but while in delivery the material she was already enjoyed teaching. Her whole performance was good enough that in sake of alternative assessment applied in microteaching subject.

Student 2 was good in welcoming the audience but she got trouble in delivering the teaching materials. She seemed lost her topic in the middle of teaching process however she prepared her assessment to audience well.

Student 3 got weak opening including welcoming the audience, introducing the topic and explaning the structure of organization, her body of content of warming up was less fact, so she got problem in organization structure part. She was not appropriate using grammar and vocabularies, a little bit louder in intonation and accent showed good, performed less movement but well prepared in physical organization showed good, explained the mastery of the subject less detail and she was reading not comprehending the material. She was good in using media, the slides were well prepared and in formal way but contrary to the fact that her creativity in improving class variation was boring and unpleasant to listen but well done in closing the class.

Student 4 was in excellent during observation. She opened the class confidently, introduced the topic clearly, explained the structure of organization in excellent way. She used very clear, logic, more evidence/fact of content in warming up and showed more example in introducing the material. It was noted that the teams gave her excellent remarks. She used correct usage of grammar and vocabularies with less conjunction, less movement, used rise up voice and intonation and well prepared during material with detail and clear explanation and the aids were variatively performed, interesting performance, pleasant to hear and excellent communication during question and answer session.

Student 5 got nervous in opening the class; welcomed the audience, introduced the topic and explained the structure. He used US style English but was good in using variative vocabularies, grammar made a lot errors, used standard pronunciation. He was less comprehending the teaching material looked like reading and moved a lot also minimal media used. At last the reflection in summing, thanking and impressing the audience were done excellent by giving some ral and religions comment towards the audience, finally he got remarks in reflection session.

Student 6 got nervous in opening the class; welcoming the audience, introducing the topic and explaining the structure. He used variative vocabularies used standard pronunciation. He was good comprehending the teaching although some materials looked and used minimal media. At last the reflection in summing, thanking and impressing the audience were done excellent by giving some moral and religions comment towards the audience.

Student 7 got nervous and poor in opening the class; poor in welcoming the audience, introducing the topic and explaining the structure were poor idea. She used simple vocabularies and repetitive, grammar made a lot errors, used standard pronunciation. She was less comprehending the teaching material and the class was noisy also she could not manage the class well, at last the reflection in summing, thanking and impressing the audience were done less without any advice in reflection session.

Student 8 was excellent in opening the class; energetic welcoming the audience, full of warming up and introducing the topic and explaining the structure very well. She used US style English excellently and very well in using variative vocabularies, less grammar errors, used standardize pronunciation. She was excelent in comprehending the teaching material and moved elegantly and media used was interesting. At last the reflection in summing, thanking and impressing the audience were done excellent by giving some moral and religions comment towards the audience.

Student 9 was excellent in opening the class; energetic welcoming the audience, full of warming up and introducing the topic and explaining the structure very well by enriching authentic. Her English was fluently and excellently and very well in using variative vocabularies, less grammar errors, used standardize pronunciation. She was excelent in comprehending the teaching material and moved elegantly and media used was interesting, at last in reflection session the reflection in summing, thanking and impressing the audience were done excellently by giving some more example from internet and printed media.

Student 10 was poor in opening the class; welcoming the audience, introducing the topic and explaining the structure. She had minimal English and used bilingual by using Bahasa Indonesia and was poor in using variative vocabularies, grammar made a lot errors, used minimal standard pronunciation. She was less comprehending the teaching material only reading and moved a lot also minimal media used. In summing, thanking and impressing the audience were done poor in reflection session.

Student 11 was poor and unstable in opening the class; welcoming the audience, introducing the topic and explaining the structure. His English was not so good and less vocabularies, grammar made a lot errors, used standard pronunciation. He was less comprehending the teaching material only reading and moved a lot also minimal media used. In reflection, he was good in summing, thanking and impressing the audience was done excellent by giving some moral and religions comment towards the audience.

Student 12 was good in opening the class; welcoming the audience, introducing the topic and explaining the structure. She used good in variative vocabularies, grammar made less errors, used standard pronunciation. She was good in comprehending the teaching material and less moved but minimal media used. In summing, thanking and impressing the audience were good. 
Student 13 got nervous in opening the class; welcoming the audience, introducing the topic and explaining the structure. She used US style English but was good in using variative vocabularies, grammar made a lot errors, used standard pronunciation. She was less comprehending the teaching material looked like reading and moved a lot also minimal media used, then score 3 she gained. At last the reflection in summing, thanking and impressing the audience were done excellent by giving some moral and religions comment towards the audience.

Student 14 met some goals and objectives in welcoming the audience, introducing the topic and explaining the structure. He used some materials in opening the class, his English was good and good in using variative vocabularies, some construction errors and grammar errors, used standard pronunciation. He was less comprehending the teaching material looked like reading and moved a lot also minimal media used. At last the reflection in summing, thanking and impressing the audience were done good and well timed.

Student 15 was excellent in creating variation at opening the class; great welcoming the audience, full of warming up and introducing the topic and explaining the structure very well by enriching authentic fact and evidents. Her English fluently and excellently and very well in using variative vocabularies, less grammar errors, used standardize pronunciation. She was excelent in comprehending the teaching material and moved elegantly and media used was interesting. In reflection session the reflection in summing, thanking and impressing the audience was done excellently by giving some authentic media and also gave rewards for those who could answer the questions.

Students 16 was creating a warm greeting and enthusiastic in opening the class; energetic welcoming the audience, full of warming up and introducing the topic and explaining the structure very well by enriching motivated videos. Her English was fluently and excellently and very well in using varieties vocabularies, minimal grammar errors, used standardize pronunciation. She was excellent in comprehending the teaching material and slightly move and media used was varies. At last in reflection session the reflection in summing, thanking and impressing the audience were done excellently by giving some more moral values example from fable and heroes story.

Student 17 was good in opening the class; welcoming the audience, introducing the topic and explaining the structure. She used US style English but was good in using variative vocabularies, grammar made a lot errors, used standard pronunciation, score 3 was given to him. She was less comprehending the teaching material looked like reading and moved a lot also minimal media used gained. At last the reflection in summing, thanking and impressing the audience were done excellent by giving some moral and religions comment towards the audience 4 in reflection session.

Student 18 was poor in opening the class; welcoming the audience, introducing the topic and explaining the structure. Her English was not good made a lot errors in grammar, used minimum standard pronunciation. She was less comprehending the teaching material looked like reading and passive and minimal media used. At last the reflection in summing, thanking and immpressing the audience were bad.

Student 19 was excellent in opening the class; energetic welcoming the audience, full of warming up and introducing the topic and explaining the structure very well by enriching authentic. His English was fluently and excellently and very well in using variative vocabularies, less grammar errors, used standardize pronunciation. He was excelent in comprehending the teaching material and moved elegantly and media used was interesting, at last in reflection session the reflection in summing, thanking and impressing the audience were done excellently by giving some more example in the authentic materials.

Student 20 was not so good in opening the class. Her English was not so fluently, many grammar errors. She was not in comprehending the teaching material. No media used in teaching. At last in reflection she was good either.

All observation was based on the students' result of observation in microteaching class. Based on all the observations above that the researcher and teams agreed that using alternative assessment, it was really effective and efficient in grading the students' achievement in microteaching skills and competence.

\section{CONCLUSION AND RECOMMENDATION}

Conclusion.

Microteaching subject was an effective way to prepare students who participate in the teaching process actively develop their knowledge and skills to be implemented in practice teaching preparation.

The common aspect of alternative assessment scoring rubric leads the whole classroom observation. Lecturer and students were actively involve from the process of teaching and learning process in classrooms, to determine through observation how lecturer achieve certain goals and how things should be done and to reach a decision on lecturer is the essence of evaluation.

Students' achievement of their own competencies develop consistently with teaching application activities. Their achievement of their own subject matter adequacy change positively as a result of application, so they could display improvement in competencies regarding Organization/Structure (Introduction: Welcome the Audience, Introduce the Topic, Explain the Structure, Body: Clear, Logic, Relevant Full of Fact, and Example), Delivery (Language: Correct Usage, Appropriate Grammar and Vocabulary, Pronunciation Intelligibility, Performance: Body Language, Eye contact, Voice, Physical Organization, Mastery of the Subject: Dept / Detail, Spoken not Reading, Aids: Slides Formal, non Formal), Reflection (Conclusion: Sum up, Thanks to the Audience, Overall Impression: Very Interesting, Pleasant and Very Good or Very Boring, Unpleasant to Listen and Poor Communication).

In micro teaching it is possible to guide students constructively by providing the necessary, adequate, and 
appropriate feedback. Working with large groups may be cumbersome, but it does not constitute a problem. Micro teaching is effective for teacher candidates in acquiring individual skills of planning lessons, grabbing learners' attention, presentation, using the necessary materials, using reinforcements, asking appropriate questions, and using body language.

Finally, based on the finding result in the previous section that the alternative assessment shows the effectiveness at implementing process teaching and learning in microteaching class. Feedbacks from lecturer and students at the end of micro teaching applications are generally positive. In micro teaching students can display their skills in Organization/Structure (Introduction: Welcome the Audience, Introduce the Topic, Explain the Structure, Body: Clear, Logic, Relevant Full of Fact, and Example), Delivery (Language: Correct Usage, Appropriate Grammar and Vocabulary, Pronunciation Intelligibility, Performance: Body Language, Eye contact, Voice, Physical Organization, Mastery of the Subject: Dept / Detail, Spoken not Reading, Aids: Slides Formal, non Formal), Reflection (Conclusion: Sum up, Thanks to the Audience, Overall Impression: Very Interesting, Pleasant and Very Good or Very Boring, Unpleasent to Listen and Poor Communication) while during observation all sample students had been already observed based on the alternative assessment.

\section{Recommendation.}

1. It is needed to find some other assessment to maximize the effectiveness and the efficiency of students in applying microteaching skills.

2. Needs more allocation of time in practicing microteaching subject to show the students' improvement in microteaching class. Although, Universitas Islam Riau especially in English study program provided 3 sks in microteaching subject, it seemed that the allocated time was still not enough.
3. Motivation of students might be improved by giving some rewards appraisal for example certificate of students' achievement.

4. Facilities to support microteaching should be improved in form of technology.

5. There is a need for a study that will involve more than one assessment to build a clear picture of what hinders and what promotes integration in microteaching skills and tools of measurement.

6. The upcoming study is supposed to include more support team and facilities improvement. This will in addition, help to make a link between what candidate teachers learn from the college and what they practice in teaching.

\section{References}

[1] Ahmad, Sabri. Strategi Belajar Mengajar Dan Micro Teaching. Ciputat: Quantum Teaching hal 148-149. 2007

[2] American Educational Research Association, American Psychological Association, \& National Council on Measurement in Education. Standards for Educational and Psychological Testing. Washington, DC: American Educational Research Association. 1999

[3] Bloom, B.S., J.T. Hasting and G.F. Madaus. Handbook on Formative and Summative Evaluation of Student Learning, McGraw-Hill Book Co, New York. 1971

[4] Darling-Hammond, L. No Child Left Behind and high school reform. Harvard Educational Review,76(4), 642-667. 2006

[5] Hamalik, Umar. Proses Belajar Mengajar. Bumi Aksara: Jakarta. 2008

[6] McAfee, O, \& Leong, D. Assessing and guiding young children's development and learning. Boston: Pearson Education, Inc. 2007

[7] Yusuf, Mudasiru Olalere. Influence of Video and Audiotapes Feedback Modes on Student Teachers' Performance -Malaysian Online Journal of Instructional Technology (MOJIT) Vol. 3, No.1, pp 29-35 April 2017. 2006

[8] U.S. Department of Education, Office of Educational Research and Improvement. Consumer Guide: Performance Assessment (ED/OERI 92-38). 1993. Retrieved November 6, 2016, from http://www.ed.gov/pubs/OR/ConsumerGuides/perfasse.html

[9] Wiggins, G. Creating Tests Worth Taking. Educational Leadership, 49(8), 26-3. 1992 